\title{
The Cultural Offices of Joe Strummer ${ }^{1}$
}

\author{
Brady Harrison
}

\author{
Well so long liberty, \\ Let's forget you didn't show. \\ - "Yalla Yalla," Rock Art and the X-Ray Style \\ Nina Simone over Sierra Leone. \\ —_Global A Go-Go," Global A Go-Go
}

As Marcus Gray writes in Last Gang in Town, "the recent history of the Mellor family could stand as a microcosm of social change in $20^{\text {th }}$-century Britain" (88). John Graham Mellor-better known as Joe Strummer, former frontman for the Clash-was born in Ankara, Turkey in 1952, the son of Ronald Ralph Mellor, a British diplomat who had been born in Lucknow, India, and Anna Girvan (née Anne MacKenzie), a nurse who had served in India during World War II. Ronald's father, Frederick Adolph Mellor, had served on the Indian Railway, and, as Gray puts it, in the course of three generations, the family witnessed the fall of the Empire and the rise of the counter-culture; a colonial and postcolonial family, they have gone "from Raj to raga" (88). The author of a number of Clash ragas-in Strummer's punk lexicon, long, "out there, free form, play, jamming" Sandinista!era songs (Clash, "Joe")—John, in his early years, lived the nomadic life of a career

Brady Harrison is Associate Professor of English at the University of Montana. His recent work has appeared in American Studies, Mattoid: A Journal of Literary and Cultural Studies, and Southwestern American Literature, among other publications, and he is currently co-editing a collection, West of Here: Critical Perspectives on Montana Literature. E-mail: harrison@selway.umt.edu. 
diplomat's son: from Turkey, the family moved to Cairo in 1954, and then onto Mexico City in 1956, then to Bonn in 1957, then to England for boarding school, and back, intermittently, to the former colonies. In the mid-1960s, while visiting his father's station in Blantyre, Malawi, John tuned in a short-wave radio to the BBC World Service. As Strummer remarks, "It was fantastic to be undeniably receiving radio from Britain. Ever since then I've always wanted to spin records on the World Service" ("Sound of Strummer"). In 1998, he got his wish, hosting a world beat program, "London Calling."

Joe Strummer-punk icon, "nightshift D.J." on the "killahertz," reborn folkraga-rocker with his new band, the Mescaleros-occupies a number of cultural offices, or positions from which to speak on music, life, politics, history, and more. From these "offices," he broadcasts around the world and into the consciousnesses of those willing to listen - to African pop, Afro-Cuban Son, American rockabilly, Columbian cumbia, German techno, Jamaican reggae, U.K. punk, and more-songs and riffs that communicate a faith in cultural openness, in human liberation and dignity, in the power of music to move people and to make them think, and that, at the same time, tilt against the foes of the disenfranchised, the working classes, and the vast majority of people who live beyond the privileges of the first world. Though he jokes that he cannot, without the help of his wife, work e-mail, Strummer makes use of the technologies of late capitalism to carry on the good fight of punk. Updating the Clash's sometimes uneven fluency in reggae and Central American folk music, he draws upon South Asian, African, Caribbean, and American beats in his own music, and spins records to a potential worldwide audience of over forty million. ${ }^{2}$ An ebullient, never-stops-talking populist, he still wants to change the world.

All this sounds, perhaps, like bollocks — or at least a little too idealistic — and we cannot, as Marx would have it, think liberation without also thinking oppression. In Strummer's case, however much he casts himself as a champion of multiculturalism and the working classes, we cannot lose sight of the negative proposition. As Fredric Jameson remarks in Postmodernism,

In a well-known passage Marx powerfully urges us to do the impossible, namely to think [the historical development of capitalism] positively and negatively all at once; to achieve, in other words, a type of thinking that would be capable of grasping the demonstrably baleful features of capitalism along with its extraordinary and liberating dynamism simultaneously within a single thought, and without attenuating any of the force of either judgement. (47)

If Strummer represents the "extraordinary and liberating dynamism" of capitalism, he also risks representing its "demonstrably baleful features." We have once more, perhaps, a figure from the metropolitan center-a figure situated personally and historically in the colonial and postcolonial worlds-appropriating the music and culture of those little able to resist such appropriations. Like George Harrison, Paul Simon, David Byrne, and others, he borrows and integrates the rhythms, phrases, and even themes of world beats into his own work and transforms them into music aimed, in the main, at consumers in the West. On the one hand, his work serves, as 
it did in the days of the Clash, to introduce listeners to different forms of music and to draw our attention to the cultures and struggles of peoples in the U.K. and around the world. On the other hand, his recent ventures can little escape the traps the Clash struggled with: contracts, consumerism, reification, commodification, and the chance that one serves, in the end, the workings of hegemony. If one moral of much Marxist theory - from Marx to Gramsci to Adorno to Althusser to Jameson to Hardt and Negri-is that we are undone, yet again, we can nonetheless see Strummer's energies as homeopathic: to use the technologies and means of capitalism to do one's best to make a more egalitarian and less violent world.

\section{"We're a garage band"}

The Clash remains Strummer's most prominent cultural office, and in order to understand his work with the BBC and the Mescaleros, we need some sense not only of his politics and pronouncements then, but also of the Clash's standing in popular and academic cultures now: the authority of the first cultural office underwrites, at least in part, the authority of the later offices. If a better lyricist and frontman than political theorist, he-along with guitarist and songwriter Mick Jones, bassist Paul Simonon, drummer Topper Headon, and sometime manager Bernie Rhodes-fashioned the Clash into punk's version of Gramsci's “organic" intellectuals. From the Westway, they tried to give shape to their generation's disaffection, and Strummer, in his role as punk icon and "all-round good geezer"("Joe Strummer") plays his old songs in concert and, on the BBC and with the Mescaleros, continues to develop the vision he first articulated with the Clash. As perhaps the most visible member of "The Only Band That Matters," he is—next to John Lydon ${ }^{3}$ - punk's most able spokesperson, and in interviews, articles, songs, documentaries, and more, he attacks — as he did in the old days_-racism, capitalism, and imperialism, and arguesagain as he did in the old days - for a more inclusive, more humane world.

While some scholars - including Jameson-have argued that dissent and refusal constitute part of the system of late capitalism, the question remains-and will be the focus of this section-whether the Clash's intervention into popular culture matters or whether, as Jameson would have it, they were beat before they began. If pinning one's hopes on a rock band seems like a dubious proposition to begin with, and if we have poor instruments for gauging the impact of cultural phenomena, we can nonetheless argue that Strummer and his bandmates constitute one counterhegemonic force in a widely diverse field of movements and interventions that will, if we accept Jameson's thesis of the "liberating dynamism" of capitalism, lead to the creation of a new political order. And, although Marx has conditioned us to think in terms of revolution, we might have to take a longer view. As Strummer remarked in a 1981 interview, changing the world is "not an overnight thing, you can't expect everything to change quickly. I figure it's an organic process" (Garbarini 51). If all this sounds, once more, like bollocks, the point here is that the latter-day Strummer, as we shall see below, wrestles with many of the same contradictions that plagued the Clash.

As one measure of the Clash's importance as a place from which to speak, we 
can examine, briefly, the band's place in contemporary popular culture. Originally formed in 1976, the Clash broke up in 1983 (when Strummer and Simonon fired Jones) or in 1985 (when Strummer called it quits on his post-Jones version of the $\mathrm{Clash}^{4}$ ), but in recent years, Strummer and his former bandmates have enjoyed a period of considerable celebration, popular and critical attention, and re-publication. In 1999, under the direction of Simonon and Jones, for example, the band released its first live record, From Here to Eternity. In the same year, under the direction of long-time Clash ally and engineer, Bill Price, much of the Clash's back catalogue was remastered and re-released. (The only post-Jones Clash recordthe much maligned and underrated $\mathrm{Cut}$ the Crap-was also remastered and reissued in 2000. $)^{5}$ In 1999, Don Letts, a D.J., video artist, and one-time member of Jones' post-Clash band, Big Audio Dynamite, also released a documentary of the band, Westway to the World, a mix of interviews and footage from Letts' earlier, abandoned project, Clash on Broadway. The subject of countless magazine covers, stories, and interviews, the band has also been the recent focus of several popular biographies, including, among others, Paul Du Noyer's The Clash, David Quantick's The Clash, and Bob Gruen's The Clash: A Photographic Documentary of the Only Band that Mattered 1977-1982. Johnny Green, long-time Clash road manager, also published a memoir about his days with the band, A Riot of Our Own. ${ }^{6}$ As if all this were not enough, the Clash have also been the subject of at least four tribute albums, all in 1999: Burning London, City Rockers, Backlash, and Police State. ${ }^{7}$ Strummer-who began his musical career as a busker-and the Clash now stand with the Beatles, the Rolling Stones, and the Who in the pantheon of British rock.

If the Clash has not received as much (rhapsodic) scholarly attention as the Sex Pistols, they have nonetheless become, as part of the complex historical and cultural phenomenon of punk, entrenched in cultural studies debates. At stake have been vexed questions of race, class, and political efficacy. In Subculture: The Meaning of Style, a seminal study of British post-war youth cultures, for example, Dick Hebdige explores the influence of reggae upon punk, and notes the Clash's openness to the music and dress of another culture: "Most conspicuously amongst punk groups, the Clash were heavily influenced not only by the music, but also by the visual iconography of black Jamaican street style. Khaki battle dress stenciled with the Caribbean legends DUB and HEAVY MANNERS, narrow 'sta-prest' trousers, black brogues and slip ons, even the pork pie hat, were all adopted at different times by various members of the group" (29). If the Clash identified with AfroCaribbean youth, Roger Sabin argues that while the band denounced racism against blacks, they had far less to say about the often more violent racism aimed toward Britain's South Asian immigrants:

On the very rare occasions when journalists did raise the subject, the response could be surprisingly unsympathetic. Thus, in a Record Mirror interview with the Clash, the band are busy outlining their anti-racist views when the subject of antiAsian violence arises, and manager Bernie Rhodes chips in: "There's a lot of Pakis that deserve it. ..." He's soon corrected by other members of the band, but 
the idea that such a comment could have been made about Afro-Caribbeans is unthinkable. (“'I Won't Let that Dago By': Rethinking Punk and Racism" 204$05)^{8}$

If some scholars have sounded the Clash on matters of race and racism, others have explored their politics. In The Triumph of Vulgarity, Robert Pattison critiques the band's agitprop:

On the Clash's Sandinista! album, Marx and Engels turn up in the 7-11, and on the cover of their Give 'Em Enough Rope Mao watches from horseback while the buzzards make a meal of a dead cowboy-the West inevitably devoured by its own greed as the Marxist hero bides his time. But on closer inspection the Clash's songs, always sardonically acute about what's wrong with the world, have little to say about any political program to make it right. (141)

In Last Gang in Town, the only book-length study of the Clash to date, Gray dissects what he terms the "myths" of the Clash-largely the inconsistencies he sees between the band's announced politics and their sometimes stormy relations with one another, their fans, and other punk acts - and faults the band for not, one supposes, bringing about the revolution: "I was also disappointed that punk did not achieve more, and that its most outspoken and-apparently-politically motivated exponents, the Clash, not only failed to deliver on so many of their promises, but ultimately failed to come to terms with their own inherent flaws and contradictions" (xiv). Not all scholars, however, take such a dim view of the band's politics and achievements. Kenneth J. Bindas, for example, offers a more sympathetic reading of Strummer and company, and argues that "the story of the Clash from 1977 to 1982 illustrates the conflicting ideology of the punks, who believed on the one hand that state and corporate control had created a new dark age, while on the other that human beings could prevail and create a more open and egalitarian society" (69). ${ }^{9}$ In recent years, biographers and cultural studies scholars have lauded the Clash's musical ferocity, but found their political mission to tell the truth about racism, capitalism, and imperialism to be a well-intentioned if sometimes messy and contradictory failure.

The prominence of the Clash in popular and academic cultures perhaps signals the completion of its evolution from garage band to cultural institution. Strummer, on that basis, enjoys a position of cultural authority, but the evolution from busker to punk icon highlights - as the comments above suggest-what has always been a matter of intense debate: how can a punk band not fall victim to its own success? Jameson, for one, argues that they never stood a chance: expressions of cultural and political defiance in the era of late capitalism "no longer scandalize anyone and are not only received with the greatest complacency but have themselves become institutionalized and are at one with the official or public culture of Western society" (5). Beat from the start, "we all, in one way or another, dimly feel that not only punctual and local countercultural forms of cultural resistance and guerilla warfare but also even overtly political interventions like those of The Clash are all somehow secretly disarmed and reabsorbed by a system of which they themselves might well 
be considered a part, since they can achieve no distance from it" (49). Jameson's "we"- the trembling, swallowed-whole theorists on the Left - can no longer attain a position "outside the massive Being of capital" (48), and in the bass line, say, to "The Guns of Brixton," we presumably should be able to hear a chant of "doom, doom, doom." Too bad for us. Or, as Jameson demonstrates again and again in his exemplary work, we can (however much Althusser might have mocked such delusions) do what we can.

Strummer and Jones, in a number of songs, acknowledge the risks of co-optation and commodification. In "Complete Control," for example, a reply to Epic/CBS for releasing "Remote Control" as a single against the band's will, they mock both the record company and themselves: "They said we' $d$ be artistically free / When we signed that bit of paper. / They meant, let's make lots of money / And worry about it later." Punk, as they put it in "(White Man) In Hammersmith Palais," could easily become another commodity, another empty spectacle: "The new groups are not concerned / With what there is to be learned. / They got Burton suits, ha you think it's funny / Turning rebellion into money." And in "Death or Glory," in perhaps their most self-lacerating and crudest moment-neither Strummer nor Jones have Lydon's flair for sneering - they worry about the possibility of their own fall to the filthy lucre: “And every gimmick hungry yob digging gold from rock'n' roll / Grabs the mike to tell us he'll die before he's sold / But I believe in this and it's been tested by research / He who fucks nuns will later join the church." Although Strummer's tongue-twisting lyrics, the tune's sing-song brightness, and Jones' mock-pretty harmonizing undercut the unexpected, defensive harshness of "he who fucks nuns," the bluntness of the second couplet nonetheless suggests that the band was well aware of the perils and contradictions inherent in being agitrockers. ${ }^{10}$ At their best, the Clash recognized that whatever the risks, not to communicate by whatever means possible constituted the greater capitulation; at their best, they used the technology and means of late capitalism to broadcast their vision of liberation.

However unsystematically, Strummer explored - and continues to explore, as we shall see below-the notion of a homeopathic engagement with the forces of commodification and reification. However vexed or unlikely a proposition-a punk rocker as Marxist theorist?-he used the media and the record industry as a means to articulate an anti-capitalist, anti-imperialist message. As Jameson speculates, one might be able to turn the forces of capitalism against capitalism, to battle reification by means of reification:

I am wondering whether some positive features of postmodernism couldn't do that as well: an attempt somehow to master these things by choosing them and pushing them to their limits. There is a whole range of so-called oppositional arts, whether it's punk writing, or ethnic writing, which really try to use postmodern techniquesthough for obvious reasons I dislike the term technique-to go through and beyond. (Stephanson 60)

While Strummer's efforts seem preliminary and modest compared to what Jameson here imagines, he nonetheless did his best to turn a position of reification-the rock 
star as commodity -into a position from which to argue against seeing others as objects, from which to counter his generation's terminal estrangement, desperation, and sense of individual and collective worthlessness.

Since the Clash remains before us in both popular and academic cultures, we can say a little about what Strummer had to say - and continues to have to sayfrom the cultural office of punk's most political band. While we do not have the space here to sound the Clash's eight or nine albums — or to say much at all about their cool-as-hell combat rock gear or mohawks or Jones' ability to pull melody from the gain or Lester Bangs' days on the road with the band, and more-we can at least gather some sense of Strummer's politics and pronouncements. In an early 1978 interview in Melody Maker, for example, he sets out his vision of the Clash: "There's so much corruption-councils, governments, industry. Everywhere. It's got to be flushed out. Just because it's been going on for a long time doesn't mean that it shouldn't be stopped. It doesn't mean that it isn't time to change." $\mathrm{He}$ continues: "People have this picture of us marching down the street with machine guns. We're not interested in that, because we haven't got any. All we've got is a few guitars, amps, and drums. That's our weaponry" (Kinneraly 8).

Although, as Pattison suggests, Strummer seems rather vague about what might actually be done to change the world-play guitar it seems-the critique that the band could sling arrows but offer little in terms of concrete action seems to miss the point. Strummer names his foes, but the interviews and lyrics and the Clash's sonic attack were not aimed so much at leveling parliament as reaching into the consciousnesses of a generation that believed it would be forever on the dole. Through his combination of attitude, Marxist critique, barking guitar, and lyrics that emerge only after thirty listenings, the singer shared a vision of the world with anyone who would listen. This vision included some basic messages: have hope; we matter; you matter; know your enemies; know your rights; believe in two minutes-fifty-nine. The most political of acts: to try to reach into somebody and change the way they think and act. And, perhaps most importantly, to create a sense of community through the pleasures of music and motion. As Eric Lott argues, "Musical culture, like most cultural products, can in its wonderful commotion create the conditions for social motion. With Jacques Attali in mind, we might say that music and its best interpreters help create or announce the existence of a community bent on getting the respect it deserves for the social desires it lets loose" (244).

Developing the arguments presented in Attali's Noise: The Political Economy of Music, a number of scholars have emphasized the roles of noise, music, and amplification in creating political energy, if only for brief historical moments. In "“Kick Out the Jams!': The MC5 and the Politics of Noise," for example, Steve Waksman offers a complex reading of the intersections of politics, Fordism, race, and rock furor in the music and performances of Detroit's late 1960s proto-punk scene. A precursor to the Clash and the Pistols, the MC5 sought to move their audience through energy and volume, sought to "translate the powerful sensations they felt from their own experience of amplified music into a broad-based movement" (67-8): "More specifically, it is here that we come to the Five's principles of 
'high-energy' music as tool of cultural revolution. For the band, the 'revolutionary' potential of their music lay in its presumed ability to drive people 'into their bodies,' to provoke what [lead singer] Rob Tyner called 'purification and resensification on all levels"" (65-6). ${ }^{11}$ For a few months, the MC5 turned up their amps and seemed poised to alter the political landscape of Michigan. ${ }^{12}$ The Clash, in a similar manner, attempted to move its audience. Often cited as a great live outfit, and providing, in the first singles and album, a raw and dislocating noise, the band offered energy, an opportunity for motion, for elation, for identity, for a feeling of community. If the first chords of a tripping-over-itself tumult like "White Riot" did not call into being the revolution, they at least drove the Clash's early audience of doldrum kids into their bodies and sent those bodies into delighted collision with one another. For a time, it seemed something might be possible.

If a jumping, gobbing audience of young punks does not quite sound like utopia, Strummer nonetheless did his best to imagine a better world. The Clash, in their early albums, rail against racism, a life on the dole, police brutality, the repressive domestic policies of the Heath and Thatcher governments, and more; in the later albums, they broaden their horizons, attempt more musical styles-especially rap and Central American folk - and attack European and American imperialism. From "1977" they progressed to "Washington Bullets." In the early, proto-punk dirge, Strummer speaks for a frustrated generation: "In 1977, I hope I go to Heaven / Cos I've been too long on the dole / And I can't work at all." In the latter, popcalypso critique of U.S. imperialism, Strummer offers a catalogue of left-wing heroes and celebrates the fall of the Somoza regime in Nicaragua: "For the very first time ever, / When they had a revolution in Nicaragua, / There was no interference from America, / Human rights in America. / Well, the people fought the leader / And up he flew / With no Washington bullets what else could he do? / Sandinista!" The soothing, yet triumphant refrain-“Sandinista!"-savors the longed-for moment: a populist victory over brutality and exploitation. Strummer and company, if we take seriously the presence of "FSLN" (Frente Sandinista de Liberación Nacional) and "FMLN" (Farabundo Martí para la Liberación Nacional) on the original covers of Sandinista! and Combat Rock, respectively, wanted revolution, wanted a world without tyranny and subjugation. Most Sandinista!-era reviewers, however, condemned the band for losing its focus on the U.K., for becoming too global, for believing its own propaganda. John Shearlaw, for one, dissected the band's politics and its attempts at musical diversity with ironic precision: "The Clash have become a messy conglomerate of present day Don Quixotes. So credible, so concerned, and so in control of their output, that from behind a mixing desk, they can now tilt at more non-existent windmills than even the Pentagon is aware of" (qtd. in Tobler 58).

As Strummer admits in the first lines of "Yalla Yalla," a slow-bum venture into techno, the world the Clash wanted to help call into being has not yet arrived: "Well so long liberty / Let's forget you didn't show, / Not in my time." But ever the optimist, he continues: "But in our son's / And daughter's time / When you get the feeling / Call, and you've got a room." A true believer, he refuses to give up, and he keeps trying, keeps thinking of ways—as the rest of this article will argue-to get 
the message out. Like Ishmael, he has another idea for us; his motto could be, "I try all things. I achieve what I can" (Melville 378). Where Jameson envisions unending entrapment, and where Gray evinces anger that a rock band could not pull off the revolution, Strummer holds onto the long view. Bit by bit, word by word, act by act, person by person, change will occur, and in some unknown day, capitalism will yield to a better system. Just as apartheid and the Soviet Union seemed to fall all at once, late capitalism could do the same. The good folks at Enron or Arthur Andersen or W.R. Grace could be, as Marx would have it, grave-diggers. Or maybe not.

\section{"This tune is going out to Marconi"}

After folding the Clash in 1985, Strummer worked a number of odd jobs, and then, as he told the Irish Times, retreated from the spotlight for most of the '90s: "I had my say and it was time for me to shut up for a while" (Boyd). In the late 80's, demoralized by the demise of the band and unhappily under contract to CBS, he played with the Pogues for a time and followed a haphazard course in soundtracks and small parts in demi-art films. He wrote songs, for example, for Alex Cox's Sid and Nancy (1986), Walker (1987), the astonishingly terrible Straight to Hell (1987), Marisa Silver's Permanent Record (1988), and appeared in Walker, Straight to Hell, and Jim Jarmusch's Mystery Train (1990). He also released one solo album, Earthquake Weather (1989), that received poor reviews and seems now to be deleted. In the '90s, his course was equally haphazard: he produced an album, Hell's Ditch (1990), for the Pogues, played with or wrote songs for bands such as Flowered Up, The Levellers, Black Grape, and the Brian Setzer Orchestra, put together the soundtrack albums for the film Grosse Point Blank (1997), and contributed to other projects, such as the Kerouac tribute, Kicks Joy Darkness (1997). ${ }^{13}$

After years of keeping a low profile, Strummer has returned to the world stage, creating two, intertwined cultural offices from which to disseminate his vision of multiculturalism and freedom from economic, political, and military exploitation: "London Calling," his BBC World Service radio program, and the Mescaleros, his new band. In both forums, he celebrates cultural diversity and explores world music. On the radio - the primary focus of this section-he spins tracks from around the globe, and with the Mescaleros, he demonstrates a fluency in a number of musical styles, including folk, rockabilly, techno, reggae, and more. To date, the band has released two critically acclaimed albums, Rock Art and the X-Ray Style (1999) and Global A Go-Go (2001), and, as Strummer tells us with characteristic fervor and humor, he spins and plays music for a global audience that feels culturally disenfranchised: "It's music for people who are beyond the parameters of the demographic fascists who decide what sells and what gets advertised and what gets on playlists. If I had five million pounds I'd start a radio station because something needs to be done. It would be nice to turn on the radio and hear something that didn't make you feel like smashing up the kitchen and strangling the cat" ("Joe Strummer and the Mescaleros"). From his two most recent cultural offices, Strummer, once more fired-up, attacks his old enemies: racism, capitalism, imperialism. 
Once more, he draws upon the technologies and means of late capitalism to do what he can to create a better world; once more, these ventures run the risk of participating in capitalism's baleful dynamism.

On August 29, 1998, from "Bush House, in the heart of London," Strummer debuted his world music show on the BBC. Beamed around the world on shortwave and available on the web, "London Calling" begins with a voice-over, an unidentified woman telling us of a future music apocalypse: "The year was 2098 in the old calendar, when it came. We called it 'The Vinyl Virus.' It took over music right across the world-destroyed reggae, cumbia, punk rock, anything that stood in its path. No real music survived-we thought. Then, from far away, across the airwaves ...."14 On cue, Strummer, with morse code tapping and air raid sirens wailing in the background: "All transmitters to pull. All receivers to boost. This is London Calling. This is London Calling ...." Wow. The post-apocalyptic, pirate radio D.J. crackling out of the ether to save our descendants from the boy bands and the Britney Spearers of the future, the machine-made pap that kills all the real music, the music that arises from the people, from life, from experience, and not from the factories of soulless later capitalism. Then, the first song, Trini Lopez's cover of Woody Guthrie's "This Land is Your Land." The perfect moment: the self-named Joe Strummer-who used to call himself "Woody" Mellor in honor of his folk hero-spinning a vision of inclusiveness and solidarity as performed by a Chicano star of the 1950s and 60s: "This land was made for you and me."

Strummer offers, in "London Calling," a vision of a world in response to late capitalism: not a world increasingly integrated by the forces of multinational capitalism, but a world increasingly united by exuberance, a sense of community, and a recognition of difference and cultural vitality. The music he plays-Harry Belafonte, Ibrahim Ferrer, Andres Landeros, Bob Marley, Elvis Presley, Ernest Ranglin and Baaba Maal, and more-serves as a celebration of diversity, indigenous instruments and forms, political and spiritual liberation, and, most of all, the pleasures of music. After Landero's "Martha Cecilia," a cumbia rave-up, Strummer barks, "If that was no toe-tapper or no body-shaker, boy, you need to see the undertaker." The D.J. offers a vision of a global village, of a less racist, less suspicious, less threatening world. Music breaks down barriers, makes the experiences and values of others accessible, offers a common ground upon which to learn about one another. Strummer would have us believe that music can make the other less other, less alien, less a reified thing that can be feared, or despised, or exploited. As he riffs after "This Land is Your Land," "Dig it! First of all, welcome to the program all peoples of the world." He goes on, "This world is your world!" While we might ask, what world?- the world endured by the vast majority of people, a world of poverty, limited opportunities, and unceasing labor, or the world of the rejuvenated metropolitan center, a world of affluence, Thames development projects, and global finance?-we might be better served to ask what cultural or ideological work such utopian energies can perform.

If the show's "format may be simple-one man and his record collection" ("Sound of Strummer"), Strummer's selections reveal as much about his notions of cultural exchange and conversation as they do about his eclectic tastes. In "Minuit," 
for example, a song played on the first show, Ranglin, a Jamaican guitarist, and Maal, a Senegalese singer and musician, offer a bright, syncopated fusion of African and Western instruments and vocals. Ranglin, who had first visited Senegal while on tour with Jimmy Cliff in the 1970s, returned to Dakar in 1998-in the company of fellow Jamaicans Ira Coleman and Dion Parson - to record with Maal and other West African artists. Weaving throughout their album In Search of the Lost Riddim elements of mento, calypso, ska, rock steady, reggae, Senegalese polyrhythms, and more, and playing mainly acoustic instruments such as the kora and hoddu - forms of West African lute-harps-Ranglin, Maal, Mansour Seck, and the other musicians undertook, as Coleman remarks, "a musical, historical, and spiritual adventure." For the Jamaicans, "This journey to the place that most black people regard as where their roots are from had proved a magical and thoroughly satisfying mission. We made a lot of new friends and created a lot of great music together with our African brothers in rhythm. Did we find the lost one? I think we came close."

To take another example - this time from Strummer's second show—in "De Camino a La Vereda," a song from the Grammy-winning and immensely popular Buena Vista Social Club, Ry Cooder teams up with Ibrahim Ferrer and other Cuban folk musicians. Cooder, a musical polymath and immersionist, traveled to Cuba in 1996 with the idea of putting together African and Cuban musicians; instead, he discovered the largely lost world of pre-revolutionary Cuban artists, and he came, as part of his life-long exploration of instruments and forms, to play with Ferrer, Rubén González, Eliades Ochoa, Omara Portuondo, and others. Both "Minuit" and "Camino" represent trans-national and trans-formal conversations, the meeting of musicians to share ideas, to call into being new and old sounds, and to bring diverse and often less familiar musicians, styles, and cultures to their audiences. These songs represent moments of community and cultural exchange; they represent an openness and generosity among peoples of different languages and nationalities. Just as the Clash, in collaboration with Jamaican D.J. and musician Mikey Dread, helped to pioneer what Hebdige calls "punk dub" (67), or a fusion of reggae and punk, Strummer foregrounds artists engaged in sharing ideas, in speaking to one another despite differences in race, nationality, or musical sensibility.

In "Global A Go-Go," the title track to the Mescaleros second album, Strummer re-asserts his faith in open communication and mutual understanding. A raveup techno-raga, the song tells the story of Joe Strummer on the BBC: "World Service bulletin / From the nightshift D.J. / All wavebands on earth / Reconnoiter on the killahertz. / This tune is going out to Marconi / To all corners of the globe. / There is no hut in the Serengeti / Where my wavelengths do not probe." Just as the Clash had the habit of singing songs about themselves-"Clash City Rockers," "This is Radio Clash," "We are the Clash," and a dozen others-Strummer continues in the self-mythologizing vein, and casts the D.J. as a multicultural hero, bringing the music, experiences, politics, desires, dreams, and more of musicians from around the world to listeners around the world. ${ }^{15}$ A global exchange, a global conversation, a global attempt at understanding and de-alienation. The song begins with bubbling and swirling synthesizer and the half-sung, half-chanted call from the 
D.J. to the people; it then erupts into guitars, drums, and unrestrained celebration: "Throwdown! Stray Cat rock in Bulawayo / Buddy Rich in Burundi / Quadrophenia in Armenia." Strummer, with the Mescaleros and guest Roger Daltry howling along, goes on: "Big Youth in Djkarta / Nina Simone over Sierra Leone / Wild sound of Joujouka in Nevada." A messy, six minute raga, the music means it; it rocks, yells, swings, gasps for air, keeps going, tells us to believe in the lyrics, in the vision. Just as in the days of the Clash, the singer asserts community, asserts the value of others, of knowing more, of understanding more. Strummer believes, and, fusing the offices of rock star and D.J., he played the song on "London Calling" in July 2001.

Strummer does not, of course, claim to be remaking the world with his radio show. A few hours on the BBC World Service, while more than hip enough, will not transform the rapacious desires of multinational capitalism into a desire, to take a line from Karl Marx's "Manifesto of the Communist Party," "to widen, to enrich, to promote the existence of the labourer" (153). In fact, he mocks his own efforts to call a better world into being: "This is Joe Strummer, and I'm here with Andy Norman at the machines. Yes, we're two men in a room, and we're broadcasting what needs to be cast. We gotta get into their heads the fountain of all wisdom. We're gonna say the unsayable and play the unplayable." While a man and compact discs cannot bring about the revolution, a show reaching a potential audience of over forty million, in whatever unquantifiable way, perhaps exerts a force against the forces of reification. The struggle here is not over the factory or the street, but over consciousness. If playing a few songs on the radio does not amount to a "ruthless criticism of everything existing," Strummer's vision of cultural exchange and openness nevertheless seeks to alter perceptions, to enrich and broaden understandings between peoples. However utopian, the reform of consciousness remains, as Marx puts it, the primary goal: "Then it will transpire that the world has long been dreaming of something that it can acquire if only it becomes conscious of it" ("Ruthless Criticism" 15). By whatever means possible, Strummer implies, you do what you can; opportunity by opportunity, you try to reach others; bit by bit, and using the global broadcast technologies of late capitalism, you try to change the world.

Whether such efforts serve the global forces-however fragmented and diverse - of liberation and pluralism or the global forces of late capitalism and empire has, of course, been a matter of intense debate in recent years. ${ }^{16}$ Although the argument has many sides, it breaks into a few major camps, with some asserting that the information revolution and the technologies of late capitalism will foster national and global pluralism and political participation and others arguing that the internet and proliferation of software-driven media serve, first and last, the commercial interests of multinational corporations. In The Electronic Republic, for example, Lawrence Grossman subscribes to the utopian dimensions of McLuhan's "global village" and asserts that the new technologies will call into being "direct democracy": "With the push of a teleprocessor button or the stroke of a telecomputer key, citizens can tell their leaders exactly what they think and what they want them to do" (12). In contrast, in The End of Politics, Carl Boggs contends that the 
future already belongs to such companies as Disney-ABC and AOL-Time Warner, and in his introduction to The Americanization of the Global Village, Richard Rollin asserts that the web and the new media are leading toward global "McDonaldization" (2). In the place of news, we get "entertainment"; in the place of debate and the open exchange of ideas, we get ads and chat; in the place of knowledge and a complex understanding of our lives and the lives of others, we get informationoverload, white noise, and bland assurances that all will be well. Once more, the majority of voices in the debate seem to offer the mantra of doom: late capitalism always wins.

"Global A Go-Go," in fact, dramatizes the dialectical proposition Jameson sets forth in Postmodernism. On the one hand, we have the good Joe, the singer-D.J. who carries on, through his latter-day offices, the good fight of punk; just as the bourgeoisie, as Marx argues, "furnishes the proletariat with weapons for fighting the bourgeoisie" ("Manifesto" 149), late capitalism furnishes Strummer with the technological weaponry to battle late capitalism. On the other, we have the potentially bad Joe, the employee of the BBC who perhaps unwittingly serves the interests of capital. As exuberant as the song may be, we cannot help but be a little unsettled by some of the imagery: "There is no hut in the Serengeti / Where my wavelengths do not probe." From London, the center of the old empire, the system reaches out, penetrates "all corners of the globe." Whether people in a hut in the Serengeti wished to be probed-or have any defenses at all-does not seem to arise as a question. The show invades, crosses borders, goes everywhere without asking permission.

Just as importantly, if the program fosters trans-national understandings, it also opens markets and promotes the sale of compact discs that enrich multinational corporations. As Jameson puts it, late capitalism constitutes "the purest form of capital yet to have emerged, a prodigious expansion of capital into hitherto uncommodified areas" (36). Such as a hut in a former colony. Or, as Hardt and Negri explain, this penetration of capital into all corners signals the transition from modernist imperialism to postmodernist empire: "In contrast to imperialism, Empire establishes no territorial center of power and does not rely on fixed boundaries or barriers. It is a decentered and deterritorializing apparatus of rule that progressively incorporates the entire global realm within its open, expanding frontiers" (xii). While Hardt and Negri hold out some hope for the multitude in the latter chapters of Empire, the sheer expansion of global capitalism, underwritten by the "U.S. constitutional project" and its "networks of agreements and associations" and "channels of mediation and conflict resolution" (182), would seem to overwhelm not only the liberating dynamism of one man and his record collection and guitar, but also the collective efforts of the new anti-imperialists.

Strummer's broadcasts from the "heart of London" raise still other, equally vexed questions. If the popularity of world beat - and its allied movements in, say, fashion or home decorating - means that the mall needs another floor, the interest of first world artists in third world forms and instruments runs the risk of participating in the old imperial processes of surveillance and appropriation. ${ }^{17}$ We need hardly say that past practices, discourses, and ontologies-as Foucault, Said, and others 
have argued-exert a profound influence on the way we act and perceive ourselves and others, and Strummer risks, as perhaps most Westerns subjects do, falling into the old modes. On the one hand, having, as a squatter-turned-punk rocker, turned his back in some measure on the life and values of his father and grandfather, and on the racism inherent in British colonialism, he embraces difference and celebrates on the air and in his own music the work of non-Western artists..$^{18}$ On the other, as a figure from the metropolitan center, he surveys and consumes the labor and products of the former colonies; he appropriates their musical styles and themes, and recasts them in a way understandable to other Westerners. He lifts songs and forms from their social and historical contexts; he perhaps contributes to their political and cultural emptying. They perhaps become-in their slick packaging and gleaming surfaces - commodity fetishes rather than expressions of lived experience. However good his intentions and however much music constitutes a form of conversation among its practitioners, Strummer enjoys-to borrow a phrase from Said's Orientalism-a "positional superiority, which puts the Westerner in a whole series of possible relationships with the Orient [or, we could add, Africa or Latin America] without ever losing him the upper hand" (7).

The analysis thus far leads us, perhaps, to a number of propositions. For one, we could argue that the doom-sayers must be correct: our daily implication in the dialectic generates, at best, a weak positive force that struggles with the negative force that may, in fact, be the stronger of the two. Call it a draw, or a slow, but sure degeneration. For another, we could argue that the positive force, however weak, carries us forward, but, faced with the overwhelming truth of Necessity and the forces of reification, commodification, and consumerism, we never stood a chance. Things may be in the saddle, but we have fallen under the hooves. For yet another, we could - and here we may, however unfashionably, indulge utopian desiresthink teleologically. We can recall Marx: "The development of Modern Industry, therefore, cuts from under its feet the very foundation on which the bourgeoisie produces and appropriates products. What the bourgeoisie, therefore, produces, above all, is its own grave-diggers. Its fall and the victory of the proletariat are equally inevitable" ("Manifesto" 151). However much the political, economic, and military agents of capitalism and imperialism — and, we must add, the philosophers of dispersion-have succeeded in undermining notions of political organization and collective progress, many would acknowledge that Marx may yet have things to tell us. Strummer-to retreat a little, perhaps, down the slopes of Olympus-seems also to believe in the possibility, if not quite the inevitability, of liberty and equality. More, the world he envisions might be calling itself into being no matter how much late capitalism might work to suppress it.

\section{"From Willesden to Cricklewood"}

In the last few paragraphs of The Rhetoric of Empire, David Spurr makes a rather unexpected turn. After offering a detailed and theoretically precise analysis of the tropes of colonial discourse, he suddenly falls into a moment of cultural romanticism: "How can I say, now, what it is like to turn from this theoretical discussion to 
the scene outside my open window, where the intervention of the non-Western world seems already at hand?" (200). He goes on, "It is a summer day in a working-class 'ethnic' neighborhood on Chicago's North Side. Mexican vendors selling coconut-flavored helados ring little bells on their pushcarts. The smell of strong coffee wafts through the air from the Assyrian café. Women in pastel-colored saris stroll in the park, where Vietnamese families are cooking outdoors" (200-01). Where-following acute historical and poststructural readings of British, French, and American speeches, travelogues, newspaper articles, and more-did this come from? The recourse to the affective gaze seems rather abrupt, and could perhaps be yet another trope- "Appreciation," or the multicultural warm fuzzy. As surprising and untheoretical as this move might at first appear, Spurr nonetheless captures an ongoing, fundamental change in the West: the "intervention" of the third world into the first.

In Empire, Hardt and Negri note this change as one of the essential pre-conditions for resistance to empire. Capitalism's demand for labor-both skilled and unskilled-has led to widespread immigration and the trans-national movement of migrant workers. In turn, the forces of empire have sought to regulate and control this movement:

Empire can only isolate, divide, and segregate. Imperial capital does indeed attack
the movements of the multitude with a tireless determination: it patrols the seas
and the borders; within each country it divides and segregates; and in the world of
labor it reinforces the cleavages and borderlines of race, gender, language, culture,
and so forth. Even then, however, it must be careful not to restrict the productivity
of the multitude too much because Empire too depends on this power. (399)

Nonetheless, even as capital attempts to keep the balance in its favor, Hardt and Negri suggest that this movement of labor will become conscious of "the central repressive operations of Empire" (399): "it is a matter of crossing and breaking down the limits and segmentations that are imposed on the new collective labor power; it is a matter of gathering together these experiences of resistance and wielding them in concert against the nerve centers of imperial command" (399). The theorists describe a world where the third moves through and settles in the first, and they imagine a growing consciousness and political power among the multitudes. ${ }^{19}$ Strummer, in his work with the Mescaleros, explores the postcolonial city and he once more does his part in the effort to reform consciousness. His songs expressin about equal measure - a longing for and celebration of multiculturalism and vibrant interdependence. If now less the agitrocker and more the thoughtful observer, he offers a hopeful take on race and what he sees as the positive changes brought about in London and the West by the forces of capitalism and imperialism.

The Mescaleros sound these changes in at least two ways. On the one hand, they experiment with a variety of musical styles and world beats. Their songs display Cuban, Latin American, African, Arabic, and Celtic influences, and most of the current line-up-Strummer, Tymon Dogg, Martin Slattery, Pablo Cook, Scott Shields, and Richard Flack ${ }^{20}$ — play a variety of instruments. They seem willing and 
able to try out almost any style or sound: while Slattery plays a "cardboard box" on "Bummed Out City," a lament about being lost in life, percussionist Cook provides "multiple personality vox" for "Shaktar Donetsk," a tale about an illegal Macedonian immigrant to Britain. And, just as Strummer's selections on "London Calling" celebrate dialogue, community, and cultural and musical diversity, the Mescaleros' facility with world beats suggests not only an engagement with the work of others, but also an identification with a broad range of cultures and experiences. Not only do they assert the value and pleasures of music, but they also assert that people can learn from one another, can learn and understand more about one another. They offer a vision of co-existence and exchange. As Strummer says of Global A GoGo, "The message of the album is that we're all going to have to learn to live together and develop a greater tolerance and get rid of whatever our fathers gave us in the way of hatred between nations" ("Joe Strummer and the Mescaleros"). ${ }^{21}$

If the music takes a global view, the lyrics speak even more directly to the movement of non-Western immigrants into the metropolitan center. In "Willesden to Cricklewood," the folk ballad that closes Rock Art and the X-Ray Style, an unidentified speaker describes walking the "lonely avenues" of North London, enjoying the people he passes, searching for moments of community: "How I would love to speak / To everybody on the street / Just for once to break the rules / I know it would be so cool." He longs for contact, longs to break down the conventions and barriers of class and race and propriety, longs to know more about the lives and experiences of the people living in the city's multi-racial neighborhoods: "Come with me and be no good / Be a madman on the street / Sing something out like Reet Petite / Let's hip-hop at the traffic lights / Ten thumbs up and smilin' bright / Crossing all the great divides / Colour, age, and heavy vibes." Over a simple arrangement of guitar, piano, and synthesizer, Strummer's rough, knowing voice takes its time, falls into the groove, shares a redeeming vision: "From Willesden to Cricklewood / As I went it all looked good / Thought about my babies grown / Thought about going home / Thought about what's done is done / We're alive and that's the one." Against all the old—and new-prejudices, hatreds, divisions, suspicions, and acts of violence, he offers simple truths: family, home, living the best one can.

In "Bhindi Bhagee," an energetic mix of Caribbean and South Asian influences, Strummer once more celebrates-this time with humor and characteristic verbal play-London's multicultural neighborhoods. The forces of multinational capitalism have called into being a new and vibrant city that boasts cultures-or at least dishes-from around the world. This time walking the "High Road," Strummer encounters a New Zealander who says he is "looking for mushy peas": "I said, no, we hadn't really got 'em around here, / I said, but we do got / Balti, Bhindi, strictly Hindi. / Dall, halal, and I'm walking down the road, / We got, rocksoul, okra, Bombay duck-ra, / Shrimp beansprout, comes with it or without." He goes on: "Welcome stranger, there's no danger, / Welcome to this humble neighborhood." As they walk, Strummer tells the Kiwi about the Mescaleros and their influences: "It's got a bit of . . um y'know / Ragga, bhangra, two-step tanga, / Mini-cab radio, music on the go! / Umm, surfbeat, backbeat, frontbeat, backseat, / There's a bunch of players and they're really letting go! / We got Brit, pop, hip hop, 
rockabilly, lindy hop." These forms come blasting out of the apartments, restaurants, and clubs in the neighborhood, and Strummer finds energy and difference wherever he looks and listens. ${ }^{22}$ The empire has made a new world.

In White Teeth, to take another recent portrait of the postcolonial city, Zadie Smith offers a comic vision of North London. The novel opens on the same streets Strummer's unnamed narrator wanders in "Willesden to Cricklewood"- "Early in the morning, late in the century, Cricklewood Broadway" (3) - and we learn that Mo Hussein-Ishmael will not permit Archie Jones, one of the novel's many protagonists, to commit suicide in front of his meat shop: "Do you hear that, mister? We're not licensed for suicides around here. This place halal. Kosher, understand? If you're going to die round here, my friend, I'm afraid you've got to be thoroughly bled first" (6). Archie, seizing his second chance at life, marries a Jamaican woman half his age, sounds the meaning of life with his best friend, Samad Miah Iqbal, a Bengali Muslim and fellow veteran of World War II, and comes into contact with a kaleidoscopic variety of people, all of whom struggle with their visions of self, city, and nation: "it makes an immigrant laugh to hear the fears of the nationalist, scared of infection, penetration, miscegenation, when this is small fry, peanuts, compared to what the immigrant fears - dissolution, disappearance" (272). Smith's London teems with life and energy — and sadness and loss-and she portrays multicultural and multiracial couples creating families — and a city — with uncertain futures: "Children with first and last names on a direct collision course. Names that secrete within them mass exodus, cramped boats and planes, cold arrivals, medical checks"' (127).

Fraught, no doubt, with the thousand-and-one tensions, conflicts, and violences that arise between peoples of different races, nationalities, religions, languages, genders, classes, sexual orientations, and more, the city that Strummer and Smith portray nonetheless displays remarkable diversity and life, and even if all this life betrays the traces and wounds of late capitalism and the history of colonization and decolonization, it possesses a complexity and vibrancy that cannot, if we are to believe Hardt and Negri, be contained. As they argue, empire "finds it impossible to construct a system of right adequate to the new reality of the globalization of social and economic relations" (394): “This impossibility is explained instead by the revolutionary nature of the multitude, whose struggles have produced Empire as an inversion of its own image and who now represents on this new scene an uncontainable force and an excess of value with respect to every form of right and law" (394). Capitalism and imperialism have set in motion bodies and forces that they cannot control, and the theorists imagine cities rather like the new London: "A new geography is established by the multitude as the productive flow of bodies define new rivers and ports. The cities of the earth will become at once great deposits of cooperating humanity and locomotives for circulation, temporary residences and networks of the mass distribution of living humanity" (397). Just as Marx saw the bourgeoisie as the agents of their own (ever-impending) demise, Hardt and Negri imagine the empire as the agent of its own undoing.

From his multiple cultural offices, Strummer offers a vision of how the world should be, and his homeopathic engagement with late capitalism arises, in part, 
from the same global forces that have been reshaping the first and third worlds over the last fifty and more years. Just as late capitalism furnishes Strummer with the technology and position of reification from which to argue against capitalism and imperialism - and thereby to attempt to reform consciousness - capitalism and imperialism may be creating the conditions for the liberation of the multitude. Or perhaps not. In Strummer's case, we see the curious doubleness that Jameson describes: he represents capitalism's liberating dynamism, and he also represents its baleful dynamism. In the same way, empire may contain a monstrously liberating dynamism, just as it most certainly contains a monstrously repressive dynamism. If, in the era of late capitalism and empire, we can perhaps more readily see selfinterest, displacement, racism, poverty, ceaseless labor, fratricide, ethnic cleansing, terrorism, civil war, and more, than we can see cooperation, liberty, and the joyful acceptance of difference, the future is unwritten. In the last few lines of "Yalla Yalla," Strummer, lost in a riff and deep in the raga's hypnotic groove, tries to see ahead: "Somebody got a vision of a homeland / From a township, / From a township window / Through a township window / Some crazy widow / Dares to have a vision / Starts seething like / Seeming like a homeland / On the plain / Not in focus yet."

\section{Notes}

A number of people and organizations have graciously assisted me in this project: my thanks, in particular, to Gill Huggett and staff at the BBC World Service's Audience Relations and to Mary O'Brien at the Irish Times. My thanks as well to Jill Bergman for her insightful comments on earlier drafts of this article, and to Michael Davis for keeping me apprised of the latest arguments regarding the web and cultural theory.

1. I have pinched my title from Quentin Anderson's "Henry James's Cultural Office," an essay that explores both James's sense of "the substance of the moral life" and his understanding of social relations. Anderson foregrounds what he sees as James's place in American culture and explores the possibility that James's writing could influence political attitudes. The title and the substance of Anderson's argument are more than suggestive for my purposes here.

2. According to the BBC, Strummer's program reaches a potential audience of 42 million: "With regard to audience figures, we aren't able to measure these by programme. The only information we can provide is the regional estimated weekly global audience for our English output, in other words, the number of potential listeners to anyone of our English programmes" (BBC World Service). The BBC was kind enough to furnish the following breakdown: total audience (English) 42 million. By region (English): Asia and the Pacific 12.8 million; Africa and the Middle East 19.8 million; Europe 3.8 million; Eurasia 0.7 million; the Americas 4.8 million.

3. For Lydon's view on the world, see his book Rotten, as well as any number of interviews and documentaries, including Julien Temple's The Filth and the Fury.

4. Although a number of musicians played, at one time or another, with the Clash, the longest-standing line-up included Strummer, Jones, Simonon, and Headon. Before Headon signed on-and after he was fired-Terry Chimes (a.k.a. Tory Crimes) drummed for the band. Keith Levene, later of John Lydon's Public Image Ltd., played guitar with the band in 
its early days. After Jones and Headon were fired — and after Chimes again called it quitsStrummer and Simonon hired Nick Sheppard, Pete Howard, and Vince White. The Clash II broke up shortly after the release of Cut the Crap (1985).

5. Although critics roundly condemned Cut the Crap when it was first released, a number of fans-as Clash web sites attest-have since found it to be one of their stronger albums. Standout tracks include "Dirty Punk," "Movers and Shakers," "Three Card Trick," and, in particular, "This Is England." Among rock critics, Jon Savage remains one of the few to say anything good about the album: "Almost everybody says this record is crap: it isn't. Try to find a copy to judge for yourself and see if you don't think 'This Is England' is the best song Joe Strummer ever wrote (or, at least, the last great Brit punk song). Cut the Crap rocks, and isn't that the general idea" (591).

6. This brief survey makes no mention of the earlier books about the Clash. See, for example, Pennie Smith's book of photographs, The Clash: Before and After, and John Tobler and Miles's The Clash.

7. Perhaps the best thing one could say about the tribute albums is that they demonstrate that the Clash was indeed a great band.

8. Sabin, in his effort to challenge what he takes as the "serious errors of emphasis" ("Introduction" 2) in studies of punk, asserts that scholars have tended to assert punk's leftist, anti-racist politics - in the form, often, of support for organizations such as Rock Against Racism and the Anti-Nazi League - and to ignore the subculture's sometimes virulent commitment to such neo-fascist, anti-immigration movements as the National Front. In "I Won't Let that Dago By," he explores, among other issues, how bands such as Sham 69 supported Rock Against Racism, but had a fan-base with strong allegiances to the National Front. He also rightly sounds the connections between punk and skinheads and neo-fascist acts such as Skrewdriver. If Sabin perhaps misrepresents what he takes as the misrepresentations of other scholars-lots of studies point out the sexism, drug abuse, and violences of the subculture-and if he perhaps insinuates too much in noting that one of Jones's pre-Clash bands went by the name, London SS, he nonetheless gives a shove in the direction of a more comprehensive view of punk.

9. Jon Savage, in England's Dreaming, likewise offers a positive view of the group and its efforts to reach out in a positive way to its audience: "if the Sex Pistols implicitly and then explicitly advocated the destruction of all values, the Clash were more human, closer to the dialogue of social concern and social realism-more in the world" (231).

10. Attempting to determine the moment the band "sold out" has always been sport for Clash fans. For Mark P, editor of one of the original punk fanzines, Sniffin' Glue, the moment came early on when the band signed with a major label instead of going with one of the small labels - Stiff or Rabid or Pogo - that flashed into being in the punk epoch of 1976 and 1977: "Punk died the day the Clash signed to CBS" (qtd. in Tobler 16). Others point to the moment when Jones authorized Levis to use "Should I Stay Or Should I Go" in one of their jean ads; the song quickly went to number one on the U.K. charts-the Clash's only number one record. But as Jones explained in an interview, everybody wears jeans. For more on the ad and responses to it-particularly Billy Bragg's—see Gray 491-92.

11. By "resensification," Tyner-according to Waksman-means a recourse to a "primitivism" the band associated with black manhood: "if 'straight,' civilized society required the dissociation of mind and body and the sublimation of physical pleasure, the Five would counter this system with a sonic assault on the senses that would, ideally, rid the body of its civilized trappings and return it to a purity of sensation that had long been lost" (66). The Clash, neither as phallocentric nor as primitivist as the MC5, relied on noise, but with different political emphases: they worried more about the dole than about - to borrow a term from the 
Five-their "rockets."

12. Cynthia Fuchs, in her reading of the contemporary queercore and riot grrrl scene, “"If I Had a Dick': Queers, Punks, and Alternative Acts," likewise cites the power of music and amplifiers to call into being a sense of community, even among diverse genders and sexualities: "Like many punk shows, this one [at Washington D.C.'s 9:30 Club in 1995] was premised on an ongoing exchange of energies and vexations: band and audience members tossed phrases - 'Fuck you,' 'Suck me'-and plastic beer cups back and forth in a ritual that, for all its potent language and contentious gesticulating, was about community and shared identity. For this night, anyway, everyone here was 'queer"' (102).

13. For this summary of Strummer's post-Clash career, I have relied in part on David Quantick's The Clash. Although it does not offer a complete overview-and although Quantick offers a number of suspect opinions-it makes note of a number of Strummer's minor ventures.

14. Although the BBC, for copyright reasons, will not release tapes or official transcripts of "London Calling," I found a "bootleg" transcription of the first four shows on Brian Powell's "White Riot," a fan webpage. I have compared the transcription with the playlists furnished by the BBC — and with my own imperfect memory - and double-checked the details with the BBC.

15. In "Techno D-Day," Strummer also sings about his work as a rave D.J.: "Well it was a techno d-day out on Omaha Beach / I was reserve D.J. playing Columbian mountain beats / Andres Landero! Ay Mi Sombrero." As Strummer spins Belafonte, the cops arrive to break up the party: "The noise inspectors with the sound detectors / Were coming on down the beach." With the crowd "ready to riot," Strummer stands his ground: "On a techno dday, a techno d-day / Out on Omaha Beach / Where the troops believe in a life of freedom / And this is all about free speech." Strummer's belief in the power of music, dancing, and the radio can also be seen at the beginning of Rock Art and the X-Ray Style: before "Tony Adams" kicks in, we hear the sounds of someone searching the dial for something worth listening to.

16. For an excellent overview of this debate, see Songok Han Thornton's "Let Them Eat IT: The Myth of the Global Village as an Interactive Utopia." This article, in part, led me to a number of the writers and works I cite here. See, as well, Andrew Herman and Thomas Swiss's The World Wide Web and Contemporary Cultural Theory: Magic, Metaphor, Power.

17. I am using these terms here in the manner suggested by David Spurr in his excellent study of colonial tropes, The Rhetoric of Empire (see, in particular, 13-42). As Spurr remarks, these tropes, or ways of thinking and writing about non-Westerners, served "the establishment and maintenance of colonial authority" (3). "Surveillance" and "appropriation" constitute ways of observing and assuming control over the lands and lives of Africans or South Asians or Native Americans.

18. During his days as a busker and with the pub rock band, the 101ers, Strummer seems to have lived for the most part in abandoned houses. For one version of Strummer's life before joining the Clash, see Gray 88-110.

19. Samir Gandesha, in "Punk Multiculturalism," argues that punk in part grew out of this mass movement of people:

The cities that gave rise to punk as an aesthetic of collision and improvisation can be characterized as postcolonial inasmuch as these spaces were in the process of becoming transformed from what were once the industrial and political centers of empire into places increasingly inhabited by erstwhile colonial subjects-West Indian workers "invited" to work on British Rail and London Transport and workers from Pakistan and Bangladesh and refugees escaping racist dictatorships in Uganda 
and Malawi. (253-54)

20. The line-up of the Mescaleros has changed over the course of their two records. The original line-up included Strummer (vocals, guitars), Antony Genn (guitars, bass, piano), Scott Shields (bass), Martin Slattery (synthesizer), Pablo Cook (drums), and a number of other session musicians. Genn, formerly of Elastica, seems to have been Strummer's primary partner, and he co-wrote a number of the standout tracks, including "Techno D-Day" and "Willesden to Cricklewood." The best track, "Yalla Yalla,"an example of what Strummer has dubbed "acid punk," comes from Strummer's earlier collaboration with Richard Norris. By the time of the second album, Global A Go-Go, Genn had departed. In addition to Strummer, Shields, Slattery, and Cook, the band now includes Strummer's old busking partner, Tymon Dogg — who played with the Clash on Sandinista! — and Richard Flank, the engineer for Rock Art and the X-Ray Style. In many ways, Global is the stronger, more coherent work. We can add that the Mescaleros are, in part, the realization of Strummer's earlier experiments with world beats in his Walker-era band, the Latino Rockabilly War.

21. Like a number of scholars and critics, Gandesha does not have much regard for the contemporary punk scene: "The spirit of Punk lies anywhere but in the bands that try to produce punk music today" (258). While some might disagree-Rancid seems to have absorbed both the musical and political lessons of the Clash, and Strummer has acknowledged Tim Armstrong's part (as Hellcat label boss) in his return to the recording studio-Gandesha does name Jones's Big Audio Dynamite, Jah Wobble_-formerly of Public Image Ltd.—and grrrl bands such as Hole, L7, and Riotgirrrls as punk's worthy successors. Jones, at the moment, seems to have closed the BAD shop.

22. The image of Strummer moving through the neighborhoods of north London, walking into and out of spaces of music calls to mind the work of a number of cultural studies scholars. As Thomas Swiss, John Sloop, and Andrew Herman-building upon the work of Jody Berland, Lawrence Grossberg, Henri Lefebvre, Michael Taussig, and others-argue in "Mapping the Beat: Spaces of Noise and Places of Music," "popular music constitutes a terrain of social and cultural identity that can be mapped in terms of its spatiality or, more precisely, as spaces of noise and places of music" (6). By walking into music, one walks-as if, they contend, by magic - into the lives and experiences of others; we walk into complex spaces and contact zones of race, class, gender, sexuality, and experience: "Within the 'magical' forcefield of sound, we become one with its place and, in so doing, mark a difference not only between the listening self and our 'normal' selves, but also between ourselves and the others on the street" (17). Spaces of power, the spaces of music, they suggest, open opportunities for "transformation and flight" (21).

23. Strummer is, of course, hardly alone in exploring and describing the new city, and while numerous musicians, writers, artists, and film makers have also studied the changes going on in the U.K., we can note, in addition to Smith, another of the most exemplary-and comic - writers of the new London. In screenplays, short stories, and novels, Hanif Kureishiperhaps best known as the screenwriter for My Beautiful Laundrette (1985) and Sammy and Rosie Get Laid (1988) — sounds the sometimes comic, sometimes harrowing intersections of multiple races, religions, sexualities, cultures, and subcultures in urban and suburban London. In The Buddha of Suburbia, Kureishi's first novel, Karim Amir, the son of an English mother and Indian father, listens "to the Clash, Generation X, the Condemned, the Adverts, the Pretenders and the Only Ones" (206), explores multiracial London- "So this was London at last, and nothing gave me more pleasure than strolling around my new possession all day. London seemed like a house with five thousand rooms, all different; the kick was to work out how they connected, and eventually to walk through all of them" (126)-and struggles to come to terms with his mixed identity: "But I did feel, looking at these strange creatures 
now - the Indians - that in some way these were my people, and that I'd spent my life denying or avoiding the fact. I felt ashamed and incomplete at the same time, as if half of me were missing, and as if I'd been colluding with my enemies, those whites who wanted Indians to be like them" (212). If Kureishi offers a comic take on the city, he also, in his second novel, The Black Album, offers a dark and violent examination of race, religion, and sexuality in the postcolonial city. Shahid Hasan, through friends he makes at college, learns of the violence directed toward South Asian immigrants: "The family had been harried-stared at, spat on, called 'Paki scum' - for months, and finally attacked. The husband had been smashed over the head with a bottle and taken to hospital. The wife had been punched" (100). Ultimately, he must choose between his friends - and their acts of retribution — and Deedee Osgood, the white woman he loves. The hatreds and violences of colonialism and racism churn through the novel, and Kureishi offers an ambivalent portrait of the city and its possibilities for both individual and collective liberation and destruction.

\section{Works Cited}

Anderson, Quentin. “Henry James's Cultural Office." Prospects: The Annual of American Cultural Studies 8 (1983): 197-210.

Attali, Jacques. Noise: The Political Economy of Music. Trans. Brian Massumi. Minneapolis: University of Minnesota Press, 1985.

BBC World Service. E-mail to the author. 18 Jan. 2002.

Bindas, Kenneth J. “'The Future is Unwritten”: The Clash, Punk and America, 1977-1982.” American Studies 34.1 (1993): 69-89.

Boggs, Carl. The End of Politics: Corporate Power and the Decline of the Public Sphere. New York and London: Guilford Press, 2000.

Boyd, Brian. "No Ordinary Joe." Irish Times 29 Apr. 2000.

The Clash. "Complete Control." The Clash. Epic, 1979.

—. "Death or Glory." London Calling. Epic, 1979.

_. "Joe_on inspiration for 'Rock the Casbah."” Rockers Galore. Epic, 1999.

—. “1977.” Super Black Market Clash. Epic, 1993.

--. "Washington Bullets." Sandinista! Epic, 1980.

—. "(White Man) in Hammersmith Palais." The Clash. Epic, 1979.

Coleman, Ira. "In Search of the Lost Riddim." In Search of the Lost Riddim. By Ernest Ranglin. Palm Pictures, 1998.

Du Noyer, Paul. The Clash. New York: St. Martin's, 1998.

Fuchs, Cynthia. "'If I Had a Dick': Queers, Punks, and Alternative Acts." Mapping the Beat: Popular Music and Contemporary Theory. Ed. Thomas Swiss, John Sloop, and Andrew Herman. Malden, MA: Blackwell, 1998. 101-18.

Gandesha, Samir. "Punk Multiculturalism." Poetics/Politics: Radical Aesthetics for the Classroom. Ed. Amitava Kumar. New York: St. Martin's, 1999. 245-59.

Garbarini, Vic. "Rude Boys: An Interview with Joe Strummer and Robert Fripp." Musician 33 (June 1981): 50-7.

Gray, Marcus. Last Gang in Town: The Story and Myth of the Clash. New York: Henry Holt, 1995.

Green, Johnny. A Riot of Our Own. New York: Faber and Faber, 1999.

Grossman, Lawrence K. The Electronic Republic: Reshaping Democracy in the Information Age. New York: Penguin, 1995.

Gruen, Bob. The Clash: A Photographic Documentary of the Only Band that Mattered 1977-1982. London: Vision On Publishing, 2001. 
Hardt, Michael, and Antonio Negri. Empire. Cambridge: Harvard University Press, 2000. Hebdige, Dick. Subculture: The Meaning of Style. New York: Methuen, 1979.

Herman, Andrew, and Thomas Swiss, eds. The World Wide Web and Contemporary Cultural Theory: Magic, Metaphor, Power. New York: Routledge, 2000.

Jameson, Fredric. Postmodernism, Or, The Cultural Logic of Late Capitalism. Durham: Duke University Press, 1991.

"Joe Strummer." Muse 12 Jan. 2002 <www.muse.ie/070400/interview/strum.html>.

"Joe Strummer and the Mescaleros: Global A Go-Go." Hellcat Records <http://www.hellcat.com/bands/index.html?ld_80440>.

“Joe Strummer's London Calling." Host Joe Strummer. BBC World Service. 29 Aug. 1998.

Kinneraly, Simon. "Strummer Speaks.” Melody Maker 52 (March 1978): 8.

Kureishi, Hanif. The Black Album. New York: Simon and Schuster, 1995.

-. The Buddha of Suburbia. New York: Penguin, 1990.

Lydon, John. Rotten. New York: Picador, 1994.

Marx, Karl. "Manifesto of the Communist Party." Marx: Selections. Ed. Allen W. Wood. New York: Macmillan, 1988. 141-68.

-. "For a Ruthless Criticism of Everything Existing." The Marx-Engels Reader. Ed. Robert C. Tucker. New York: W.W. Norton, 1978. 12-15.

Melville, Herman. Moby-Dick. New York: Penguin, 1988.

Pattison, Robert. The Triumph of Vulgarity: Rock Music in the Mirror of Romanticism. New York: Oxford University Press, 1987.

Quantick, David. The Clash. New York: Thunder's Mouth Press, 2000.

Rollin, Roger. "Introduction: On Comparative Popular Culture, American Style." The Americanization of the Global Village: Essays in Comparative Popular Culture. Ed. Rollin. Bowling Green: Bowling Green State Popular Press, 1989. 1-17.

Sabin, Roger. "Introduction." Punk Rock: So What? Ed. Sabin. New York: Routledge, 1999. 1-13.

—. “'I Won't Let that Dago By': Rethinking Punk and Racism." Punk Rock: So What? Ed. Sabin. New York: Routledge, 1999. 199-218.

Said, Edward W. Orientalism. New York: Vintage, 1978.

Savage, Jon. England's Dreaming: Anarchy, Sex Pistols, Punk Rock, and Beyond. Expanded edition. New York: St. Martin's, 2001.

Smith, Pennie. The Clash: Before and After. Boston: Little, Brown and Company, 1980.

Smith, Zadie. White Teeth. New York: Vintage, 2000.

Spurr, David. The Rhetoric of Empire. Durham: Duke University Press, 1993.

Stephanson, Anders. "Regarding Postmodernism-A Conversation with Fredric Jameson." Postmodernism/Jameson/Critique. Ed. Douglas Kellner. Washington: Maisonneuve Press, 1989. 43-74.

"The Sound of Strummer." BBC World Service. 13 Oct. $2000<$ <http://www.bbc.co.uk/ worldservice/arts/highlights/001013_strummer.shtml>.

Strummer, Joe, and the Mescaleros. "Bhindi Bhagee." Global A Go-Go. Hellcat Records, 2001.

—. "Global A Go-Go." Global A Go-Go. Hellcat Records, 2001.

—. "Techno D-Day." Rock Art and the X-Ray Style. Hellcat Records, 1999.

—. "Willesden to Cricklewood." Rock Art and the X-Ray Style. Hellcat Records, 1999.

—. "Yalla Yalla." Rock Art and the X-Ray Style. Hellcat Records, 1999.

Swiss, Thomas, John Sloop, and Andrew Herman. "Mapping the Beat: Spaces of Noise and Places of Music." Mapping the Beat: Popular Music and Contemporary Theory. Ed. Swiss, Sloop, and Herman. Malden, MA: Blackwell, 1998. 3-29.

Temple, Julien, dir. The Filth and the Fury. New Line, 2000. 
Thornton, Songok Han. "Let Them Eat IT: The Myth of the Global Village as an Interactive Utopia." CTHEORY: Theory, Technology and Culture 25.1-2 (2002): Article 103. Tobler, John, and Miles. The Clash. New York and London: Omnibus Press, 1983.

Waksman, Steve. “'Kick Out the Jams!': The MC5 and the Politics of Noise." Mapping the Beat: Popular Music and Contemporary Theory. Ed. Thomas Swiss, John Sloop, and Andrew Herman. Malden, MA: Blackwell, 1998. 47-75. 